\title{
COMMENTS
}

\section{Separation of Powers and Judicial Service on Presidential Commissions}

The President often asks federal judges to serve on commissions which recommend and inform legislative or executive action. Chief Justice Warren, for example, stepped out of his robes to supervise the investigation of President Kennedy's assassination. ${ }^{1}$ Justice Roberts helped a commission to study the attack on Pearl Harbor. ${ }^{2}$ Yet this kind of judicial aid to the executive has not been restricted to moments of national crisis; judges have served on commissions dealing with postal costs, ${ }^{3}$ international law, ${ }^{4}$ crime and violence, ${ }^{5}$ and the civil service. ${ }^{6}$

Despite its prevalence, judicial participation on presidential

${ }^{1}$ See Exec. Order No. 11,130, 3 C.F.R. 795 (1963); see also Report of the WarRen Commission on the Assassination of President Kennedy (N.Y. Times ed. 1964).

2 Exec. Order No. 8,983, 3 C.F.R. 1046 (1941).

${ }^{3}$ President Taft appointed Justice Charles Evan Hughes to chair a special commission investigating the cost to the Postal Service of handling second-class mail. S.J. Res. 147, 36 Stat. 1458 (1911). See Nonjudicial Activities of Supreme Court Justices and Other Federal Judges, Hearings Before the Subcommittee on Separation of Powers of the Senate Committee on the Judiciary, 91st Cong., 1st Sess. 139 (1969) (statement of Alexander M. Bickel) [hereinafter cited as Hearings].

The President's Commission for the Observance of the Twenty-fifth Anniversary. of the United Nations in 1970, established to recommend whether the United States should participate in the United Nations, included Judge Robert M. Duncan as a member. See Report of the President's Commission for Observance of the Twenty-Fifth ANNIVERSary of the United Nations REport (1971).

- See Exec. Order No. 11,236, 3 C.F.R. 329 (1965) (establishing the President's Commission on Law Enforcement and Administration of Justice with Judges James B. Parsons and Luther W. Youndahl as members); Exec. Order No. 11,412, 3 C.F.R. 726 (1968) (appointing Judge A. Leon Higginbotham to the National Commission on the Causes and Prevention of Violence).

- See Pritchett, Stanley Reed, in III The Justices of the United States Supreme CourT, 1789-1969, at 2376 (L. Friedman \& F. Israel eds. 1969) (discussing Justice Reed's appointment as Chairman of the Commission on Civil Service Improvement).

Judges have also served in other executive branch positions. President Truman, for example, appointed Justice Jackson as chief prosecutor at the Nuremberg war-crimes trials. See Eugene Gerhart, America's Advocate: Robert H. Jackson 21-25 (1958). 
commissions has remained largely unchallenged in the courts. Recently, however, two courts of appeals considered whether service by federal judges on presidential commissions is unconstitutional as a violation of the doctrine of separation of powers. Both cases concerned the President's Commission on Organized Crime, a commission established by President Reagan to investigate organized crime and to recommend legislation based on its investigations. ${ }^{7}$ The courts disagreed about whether this form of extra-judicial activity violated the Constitution, ${ }^{8}$ thus casting doubt on the future ability of the President to appoint judges to serve on presidential commissions.

This comment provides a framework for analyzing the constitutionality of judicial service on various types of presidential commissions. Part I provides an overview of presidential commissions and their differentiating characteristics, and presents the views of the two circuits that have considered their constitutionality. Part II identifies the two major separation of powers tests used by the Supreme Court and explains their purposes. Part III applies these two tests and identifies the kinds of presidential commissions for which judicial service is most troublesome as a constitutional matter. The comment concludes that a body with characteristics like the President's Commission on Organized Crime is one for which judicial participation is most inappropriate.

\section{Presidential Commissions and Judicial Service}

\section{A. The Role of Presidential Commissions}

Presidential commissions currently play an important and accepted role in the executive branch. ${ }^{\circ}$ These commissions are simi-

The commission was established in 1983, see Exec. Order No. 12,435, 3 C.F.R. 202 (1983), and issued its final report and disbanded in 1986, see Crime Panel and Its Final Report, N.Y. Times, April 12, 1986, § 1, at 1, col. 2. The two judges who served on the commission were the late Justice Potter Stewart, who at the time sat occasionally as a judge on various federal courts of appeals, and Irving $R$. Kaufman, Judge for the United States Court of Appeals for the Second Circuit.

8 The Eleventh Circuit held that it did in In re Application of President's Commission on Organized Crime Subpoena of Scaduto, 763 F.2d 1191 (11th Cir. 1985); the Third Circuit reached the opposite result in In re President's Commission on Organized Crime Subpoena of Scarfo, 783 F.2d 370 (3d Cir. 1986).

- As of 1985, there were 51 presidential commissions. For a complete list of these commissions, see Federal Advisory Committees: Thirteenth Annual Report of the PresiDENT, FISCAL YeAR 1984, at 51 (1985).

The use of presidential commissions has increased in recent years. Prior to 1972, the President was able to establish a special commission to study or investigate a particular area by simply issuing an executive order establishing such a commission. But presidential com- 
lar in fundamental ways: they are financed by the executive branch, their members serve at the pleasure of the President, and their work usually consists of producing comprehensive reports. Despite these similarities, however, the commissions are more notable for their differences. For constitutional purposes, the important differences arise from the powers given to commissions, the purposes for which they are established, and the subject-matter on which they concentrate.

1. Powers of the Commission. The executive order which creates a presidential commission usually defines the body's powers. These powers vary dramatically. Some commissions hold very limited powers. For example, the President's Commission on Law Enforcement and Administration of Justice was authorized only to meet with various government officials and agencies, take surveys, and sponsor conferences. ${ }^{10}$ Other commissions, by contrast, receive broad "law enforcement" powers. The President's Commission on Organized Crime, the body challenged in recent litigation, was authorized to issue subpoenas requiring attendance, testimony, and the production of information, to seek judicial enforcement of its subpoenas, to issue orders compelling testimony under the federal immunity statute, and to obtain information through the judicially authorized use of wiretaps. 11

2. Purposes of the Commission. Presidential commissions also differ substantially in their purposes. Although all commissions work with an eye to changing the law-hence, the President's interest in them-they differ in the specificity of changes they recommend. Some commissions can be described as "enactment intensive," others as "policy intensive."

Enactment-intensive commissions are formed to study and recommend specific laws or executive action. Presidents have used

missions became so numerous and so much a part of the operation of the executive branch that in 1972 Congress enacted the Federal Advisory Committee Act, 5 U.S.C. app. $2, \S \S 1-15$ (Supp. 1985), which prescribes regulations to be followed by commissions established by the President, Congress, and administrative agencies. Thus, presidential commissions have become an established part of the executive branch of government, recognized as a "useful and beneficial means of furnishing expert advice, ideas, and diverse opinions to the Federal Government." Id. § 2(a).

10 The Commission was established in 1965 by President Johnson. See Exec. Order No. 11,236, 3 C.F.R. 329 (1965); see also H. Ted Rubin, The Courts: Fulcrum of the Justice SySTEM 243 (2d ed. 1984). In the process of developing its findings and recommendations, the Commission "called three national conferences, conducted five national surveys, held hundreds of meetings, and interviewed tens of thousands of persons." The Challenge of Crime in a Free Society: A Report by the President's Commission on Law Enforcement and Administration of Justice 37 (1968) [hereinafter cited as The Challenge of Crime].

1 See Pub. L. No. 98-368, 98 Stat. 490 (1984). 
them to recommend specific changes in income maintenance programs, ${ }^{12}$ utilization of water resources, ${ }^{13}$ and the nation's financial structure. ${ }^{14}$ The Law Enforcement Commission, for example, was enactment intensive; the President instructed it to study the causes of crime and delinquency and to make legislative recommendations for preventing crime and improving the administration of criminal justice. ${ }^{15}$ The commission's findings and recommendations directly influenced congressional enactment in 1968 of the Safe Streets and Crime Control Omnibus Act. ${ }^{16}$ Similarly, the Organized Crime Commission was charged principally with making comprehensive recommendations for new legislation and law enforcement measures to combat organized crime. ${ }^{17}$

Unlike enactment-intensive commissions, policy-intensive commissions are not formed to recommend any specific action. Instead, they merely examine and compile findings about certain subject areas, and help formulate and advise general policy. ${ }^{18} \mathrm{Pol}-$ icy-intensive commissions have researched such varied subjects as highway safety, foreign aid, human rights, the budgetary process, student protests, and mental retardation. ${ }^{19}$

12 See Poverty Amid Plenty: The American Paradox, Report of the President's Commission on Income Maintenance Programs (1969).

13 See A Water Policy for the American People: General Report of the President's Water Resources Policy Commission (1950).

14 See The Report of the President's Commission on Financial Structure and RegULATION (1971).

${ }^{15}$ See Exec. Order No. 11,236, 3 C.F.R. 329 (1965). In all, the Commission made more than 200 specific recommendations. The Challenge of Crime, supra note 10 , at 37 .

16 H.T. RuBin, supra note 10, at 243.

17 Exec. Order 12,435 § (2)(a), 48 Fed. Reg. 34,723 (1983).

${ }^{18}$ An extreme form of policy-intensive commission comprises cultural or celebratory commissions, which are formed to give advice about a particular celebration or cultural event or to provide ongoing assistance to particular cultural institutions. An example of the former is the current commission established to organize the bicentennial celebration of the signing of the Constitution. See Pub. L. 98-101, 97 Stat. 719 (1983). Examples of the latter are several statutes that have provided that the Chief Justice or another article III judge serve on a cultural commission. The Chief Justice is a member of the Board of Regents of the Smithsonian Institution, see 20 U.S.C. $\$ 42$ (1982), a trustee of the National Gallery of Art, see id. $\S 72$, a trustee of the Joseph H. Hirshorn Museum and Sculpture Garden, see id. $\S 76 \mathrm{bb}(\mathrm{b})$, and has been given the power to appoint a member of the judiciary to the National Historical Publications Commission, see 44 U.S.C. § 2501 (1982).

19 For reports by these commissions, see Mobility Without Maymem: Report of The Presidential Task Force on Highway Safety (1970); U.S. Foreign Assistance in the 1970s: A New Approach: Report to the President grom the Task Force on International Development (1970); To Continue Action for Human Rights: Report of The President's Commission for the Observance of Human Rights Year (1968); Report of The President's Commission on Budget Concepts (1967); The Report of the President's Commission on Campus Unrest (1970); A Proposed Program for National action to Combat Mental Retardation: Report of The President's Panel on Mental Retardation 
An example of a policy-intensive commission is the President's Commission on Postal Organization, established in 1967 to "conduct the most searching and exhaustive review ever undertaken" of the American postal system and to "determine whether the postal system as presently organized is capable of meeting the demands of our growing economy and our expanding population."20 The commission investigated postal operations and service and made recommendations regarding reorganization, management techniques, and employment practices. ${ }^{21}$ Similarly, the Warren Commission and the Pearl Harbor Commission were policy-intensive commissions formed to investigate the facts surrounding particular controversies. ${ }^{22}$

Of course, presidential commissions do not always fit neatly into either category. Some commissions may be directed both to recommend specific enactments and to help shape general policy. And the actual work done by commissions may sometimes take them far from their original purposes. Most commissions, however, operate with primary purposes that are either enactment-intensive or policy-intensive.

3. Subject-Matter of the Commission. The examples given so far show how widely the subject-matter of presidential commissions can vary. Along these lines, however, it is important to distinguish between commissions of wide or controversial public interest and those of interest to only a narrow group of people. The former category would include the recently formed commission to investigate the accident to the space shuttle Challenger. ${ }^{23}$ Because it deals with a subject of great popular interest, its proceedings were subject to regular media exposure, and the public became more aware of its membership.

Other commissions draw far less public attention, although they deal with issues that are important and controversial to many. A good example is a commission whose work relates to judicial administration, perhaps focusing on rules of civil procedure and evidence, or on housekeeping rules, such as the number of law clerks allowed to each federal judge. Although judges may have a serious

(1962).

${ }^{20}$ See Towards Postal Excellence: Report of the President's Commission on Postal Organization, at iii (1968).

21 See id. at 1-6.

${ }_{22}$ See Exec. Order No. 11,130, 3 C.F.R. 795 (1963) (assassination of President Kennedy); Exec. Order No. 8,983, 3 C.F.R. 1046 (1941) (invasion of Pearl Harbor).

${ }^{23}$ See Exec. Order No. 12,546, 51 Fed. Reg. 4475 (1986) (creating the Presidential Commission on the Space Shuttle Challenger Accident). 
interest in such issues, a commission could probably consider them without generating much of a public stir.

\section{B. President's Commission on Organized Crime}

Despite widespread service by federal judges on presidential commissions, the practice lacks universal acceptance. Participation by federal judges in the executive branch in any capacity has been criticized throughout the history of the federal government. ${ }^{24}$ The particular practice of serving on presidential commissions has been criticized by judges, ${ }^{25}$ legislators, ${ }^{26}$ and commentators. ${ }^{27}$ Only re-

24 Critics of Justices Jay's and Ellsworth's positions as ambassadors maintained that these appointments were "precedents for allowing the President to influence the judges by promising them additional offices in return for favorable decisions." See Hearings, supra note 3, at 784 (abstract of doctoral dissertation by Russell Wheeler). Senator Daveiss stated that these positions were "breaking in upon what I would have a fundamental principle, you ought to insulate and cut off a judge from all extraneous inducements and expectations; never present him the hope of promotion; for no influence is more powerful in the human mind than hope-it will in time cause some judges to lay themselves out for presidential favor, and when questions of state occur, this will greatly affect the public confidence in them, and sometimes deservedly." Mason, Extra-judicial Work for Judges: The Views of Chief Justice Stone, 67 HARv. L REv. 193, 194 (1953). More recently, Senator Ervin noted that, "[w]hile Justices have accepted opportunities to perform extrajudicial functions since the first days of the Constitution, criticism of the practice dates back just as far," and added that "Madison and Jefferson strongly opposed the political and governmental activities of the Federalist judges." Hearings, supra note 3, at 9-10.

In 1972, the American Bar Association adopted several provisions restricting the extrajudicial activities of judges. These rules admonish judges not to "accept appointment to a governmental committee, commission, or other position that is concerned with issues of fact or policy on matters other than the improvement of the law, the legal system, or the administration of justice," but allow a judge to represent the government "on ceremonial occasions or in connection with historical, educational, and cultural activities." CODE OF JUdicial CoNDuct Canon 5(G) (1972).

${ }^{2 s}$ Several judges have turned down appointments to commissions. Declining to serve as chairman of the United States Ballot Commission set up to handle the problem of soldiers voting during the war, Chief Justice Stone said: "I regard the performance of such a function as incompatible with obligations which I assumed with the office of Chief Justice, and as likely to impair my usefulness in that office. . . . [A]ction taken by the Chief Justice in connection with the administration of the proposed legislation might become subject to review in the Court over which he presides and that it might have political implications and political consequences which should be wholly disassociated from the duties of the judicial office." Letter From Chief Justice Harlan F. Stone to Senator Arthur H. Vandenberg, 89 Cong. Rec. 9791 (1943). Similarly, in 1898 Chief Justice Fuller rejected President McKinley's offer of a position on the Spanish-American War Peace Commission, asserting that "it is far wiser that the Chief Justice should not participate in public affairs." WiLlard KING, Melville Weston Fuller, Chisf Justice of the United States 246-47 (1950). This turned out to be a wise decision since the Treaty of Peace later came before the Court. Id. at 247.

Justice Roberts regretted his own service on two commissions. "I accepted, at the hands of two Presidents, commissions to do work not strictly of a judicial nature. I have every reason to regret that I ever did so. I do not think it was good for my position as a justice, nor do I think it was a good thing for the Court." Roberts, Now Is the Time: Fortifying the 
cently, however, has judicial service on presidential commissions been challenged in the courts.

The consideration of constitutional challenges to the Organized Crime Commission by the Eleventh and Third Circuits reveals an uncertainty in applying separation of powers analysis to judicial service on presidential commissions: although both cases purported to apply the same legal standard to similar facts, they came to opposite conclusions. In In re Application of President's Commission on Organized Crime Subpoena of Scaduto, ${ }^{28}$ the Eleventh Circuit considered a prisoner's challenge to a subpoena issued by the Commission, and to a writ of habeas corpus ad testificandum issued by a federal district judge to compel the prisoner's testimony before the Commission. ${ }^{29}$ In In re Application of President's Commission on Organized Crime Subpoena of Scarfo, ${ }^{30}$ the Third Circuit also considered a challenge by an individual who refused to answer a subpoena to testify before the Commission. But in Scaduto the

Supreme Court's Independence, 35 A.B.A.J. 1, 2 (1949). Justice Roberts was accused of bias and unfairness while on the German-American Mixed Claims Commission, and the investigation of the Pearl Harbor disaster, which he chaired, was so controversial that Congress investigated his investigation. Id.

Chief Justice Warren also had misgivings about serving on the Warren Commission. When he was first asked to participate, he declined, explaining: "First, it is not in the spirit of the constitutional separation of powers to have a member of the Supreme Court serve on a presidential commission; second, it would distract a Justice from the work of the Court, which had a heavy docket; and third, it was impossible to foresee what litigation such a commission might spawn, with resulting disqualification of the Justice from sitting in such cases." Earl Warren, The Mrmoirs of EarL Warren 356 (1977).

26 In 1947 a report by the Senate Committee on the Judiciary strongly condemned the use of federal judges by the executive branch. The report contemplated that routine movements between judicial and executive offices might impair "the integrity and independence of the judicial office" and diminish "the public regard" for the federal bench. S. Exrc. RRP. No. 7, 80th Cong., 1st Sess. 1 (1947).

More recently, in 1969, Senator Ervin proposed a bill meant to "enforce the principle of separation of powers" by prohibiting judges from participating in any nonjudicial governmental duties. See Hearings, supra note 3, at 7-8.

${ }^{27}$ Concerning Senator Ervin's bill, Alexander Bickel stated that routine executive participation by a Justice would make him "a member, to all intents and purposes, of the presidential bureaucracy." According to Bickel, this both drains time away from judicial work and risks prejudice in the Court's work. Hearings, supra note 3, at 137-38.

For discussions of extra-judicial activities generally, see Mason, supra note 24, at 193; McKay, The Judiciary and Nonjudicial Activities, 35 LAW ANd Contemp. ProB. 9 (1970); Slonim, Extrajudicial Activities and the Principle of the Separation of Powers, 49 Conn. B. J. 391 (1975); Wheeler, Extrajudicial Activities of the Early Supreme Court, 1973 SuP. Cr. REv. 123; Note, Extrajudicial Activity of Supreme Court Justices, 22 STAN. L. REv. 587 (1970).

\footnotetext{
20 763 F.2d 1191 (11th Cir. 1985).

29 Id. at 1193-94.

so 783 F.2d 370 (3d Cir. 1986).
} 
subpoena was quashed; in Scarfo it was upheld.

Both courts stated that the doctrine of separation of powers would be violated if judges' service on the Commission interfered with the functioning of the judicial branch. ${ }^{31}$ The Eleventh Circuit held that it did because judicial service on the Commission threatened the impartiality of the judiciary. The court was especially concerned that judges would develop a general bias against particular organized crime suspects and in favor of law enforcement officials which would affect impartiality and, even if overcome, would threaten the faith of litigants in the judge's impartiality. ${ }^{32}$

In rejecting these arguments, the Third Circuit emphasized that there is a long historical practice of judicial service on extrajudicial government bodies, ${ }^{33}$ that service on the commission was voluntary, ${ }^{34}$ and that it was undertaken in the judges' individual, rather than official, capacity. ${ }^{35}$ To the specific concern that judicial service might result in an "appearance of bias," the court responded that judges could simply recuse themselves. ${ }^{36}$ And the burdens of any dislocation that might result from such disqualification would be minimal; disqualified judges could simply hear different cases. ${ }^{37}$ Nor did the court find any support for the contention that commission service would so drain judges' time as to impair the judicial function. ${ }^{38}$

Thus the Eleventh and Third Circuits do not disagree about the terms of the constitutional issues. They differ only about the factors that might result in impairment of the judicial function and the proper weight to be assigned to each factor. What is needed is an analytical framework that considers the problem in light of the particular constitutional concerns raised by the different characteristics of presidential commissions.

\section{The Doctrine of Separation of Powers}

A. Structural Development

The doctrine of separation of powers occupies a unique posi-

\footnotetext{
31763 F.2d at 1197; 783 F.2d at 379.

32763 F.2d at 1197.

s3 783 F.2d at $377-78$.

st Id. at 376 .

ss Id. at 381 .

${ }^{36}$ Id.

${ }^{37}$ Id.

${ }^{38}$ Id.
} 
tion in American constitutional law. Although long recognized by the Supreme Court as a constitutional requirement, ${ }^{39}$ the doctrine is not explicitly stated in the Constitution. Instead, the Court has implied the doctrine from the structure of the Constitution's allocation of power among the three branches of the federal government. ${ }^{40}$

This structure is one of strict separation of the branches coupled with clearly delineated interaction designed to protect each branch from encroachments by the others. The strict separation is accomplished by the creation of distinct legislative, executive, and judicial branches, ${ }^{41}$ each with defined powers. In addition to this "negative check," the Constitution also gives each branch limited powers over the others: for example, the Senate has the power to impeach the President, ${ }^{42}$ the President may veto bills enacted by Congress, ${ }^{43}$ Congress may prescribe the jurisdiction of lower federal courts, ${ }^{44}$ and the courts possess the power of judicial review of executive and legislative actions. ${ }^{45}$

A constitutional structure that adheres to the doctrine of separation of powers may be seen as serving many different purposes. The doctrine preserves the rule of law by requiring that the people who make the law be different from the people who execute and apply it, which makes possible greater impartiality, uniformity,

30 See, e.g., Buckley v. Valeo, 424 U.S. 1, 123 (1976); O'Donoghue v. United States, 289 U.S. 516, 530 (1933); Springer v. Philippine Islands, 277 U.S. 189, 201 (1928).

40 See, e.g., Buckley, 424 U.S. at 124; Myers v. United States, 272 U.S. 52, 116 (1926).

4 Article I of the Constitution declares: "All legislative Powers herein granted shall be vested in a Congress of the United States." U.S. ConsT. art. 1, $\$ 1$. Article II vests the executive power "in a President of the United States of America." Id. art. II, $\S 1$. Article III declares: "The judicial Power of the United States, shall be vested in one supreme Court, and in such inferior Courts as the Congress may from time to time ordain and establish." Id. art. III, \& 1 .

42 Id. art. I, \& 3 , cl. 6 .

43 Id. art. I., $\$ 7$, cl. 2.

14 Id. art. III, \& 1 .

15 See Marbury v. Madison, 5 U.S. (1 Cranch) 137 (1803).

According to Madison, "the great security against a gradual concentration of the several powers in the same department consists in giving to those who administer each department the necessary constitutional means and personal motives to resist encroachments of the others." The Fedrralist No. 51, at 321-22 (Mentor ed. 1961) (J. Madison).

Thus, in defending the Constitution against the criticism that the branches were not separate enough, Madison emphasized that their separation is enhanced by giving some powers properly belonging to one branch to another branch. For only by giving each branch powers to defend and protect itself from encroachments and interferences by another branch could the independence of each branch be maintained. Id.; see also Buckley, 424 U.S. at 122 ("The Framers regarded the checks and balances that they had built into the tripartite Federal Government as a self-executing safeguard against the encroachment or aggrandizement of one branch at the expense of another"). 
and predictability in the application of sanctions. ${ }^{46}$ The doctrine also increases the probability that the law will serve the common interest rather than the interests of the particular individuals creating it, again because those who create the law will not execute and apply it. ${ }^{47}$ In addition, the doctrine reduces the possibility that government will be controlled by one faction, because the positive checks each branch holds over the others make it necessary for a faction to control all three branches in order to have its way. ${ }^{48}$

These purposes reflect a common theme: the avoidance of unchecked power. ${ }^{49}$ In its historical context, the separation of powers was a way to reconcile the need for a federal government with the fear, freshly raised by the Founders' experience with English monarchy, that centralized government would be oppressive. ${ }^{50}$ If the different aspects of governing-making, enforcing, and interpreting the law-could be placed in separate hands, no single group or person could use the full force of government against individual freedom. ${ }^{51}$

s6 See W.B. Gwyn, The Meaning of the Separation of Powers 127, 128 n.1 (1965) (Tulane Studies in Political Science, vol. 9); David Epstein, The Political Theory of The Federalist 127-30 (1984).

47 W. GwYN, supra note 46, at 13-16, 127; D. EPSTEIN, supra note 46, at 129.

4. W. GWyn, supra note 46, at 126-28; see also Sunstein, Interest Groups in American Public Law, 38 Stan. L. Rev. 29, 44 (1986).

In some respects, a structure of separate powers can also make the government more efficient. W. GwYN, supra note 46, at 127; see also Banks, Efficiency in Government: Separation of Powers Reconsidered, 35 SYRAcuse L. REv. 715 (1984).

49 W. GwYN, supra note 46 , at 127-28.

so See Levi, Some Aspects of Separation of Powers, 76 Colum. L. Rev. 371, 373-76 (1976). The doctrine was regarded in 1776 as essentially a means of controlling executive power, particularly by increasing the power of the legislature. Id. at 374 . Thus, under the Articles of Confederation considerable power was vested in the legislature. However, by the time of the Constitutional Convention of 1787, it was believed that although legislatures needed to be powerful, majority rule tended to be unstable and inefficient. Thus, the separation of powers embodied in the Constitution was in part a reaction to the unchecked powers exercised by individuals in the legislatures. Id.

For helpful discussions of the framers' conception of the doctrine of separation of powers, see Gordon Wood, The Creation of the American Republic 1776-1787, at 547-53 (1969); Ervin, Separation of Powers: Judicial Independence, 35 LAw \& ContEMP. ProB. 108, 108-18 (1970); Sharp, The Classical American Doctrine of "The Separation of Powers," 2 U. CHI. L. Rev. 385 (1935); Wright, The Origins of the Separation of Powers in America, 13 ECONOMIA 169 (1933).

s1 "The accumulation of all powers, legislative, executive, and judiciary, in the same hands, whether of one, a few, or many, and whether hereditary, self-appointed, or elective, may justly be pronounced the very definition of tyranny." THE FEDERALIST No. 47, supra note 45, at 301 (J. Madison). Thomas Jefferson also warned that unless the powers of government were divided into three independent branches, the government would be no more than an elective despotism, which "was not the government we fought for." THOMAS JEFrERson, Notes on the State of Virginia Constitution 120 (W. Peder ed. 1955); see also Myers 
Quoting Montesquieu, James Madison explained that tyranny would result from a concentration of the three powers in the same body because " " $[\mathrm{w}]$ ere the power of judging joined with the legislative, the life and liberty of the subject would be exposed to arbitrary control, for the judge would then be the legislator. Were it joined with the executive power, the judge might behave in all the violence of an oppressor." "r2 Not surprisingly, the Constitutional Convention rejected several proposals to require judges to participate in the legislative process. ${ }^{53}$

Protection against unchecked power requires not only that there be three separate branches of government, but that the personnel in those branches be separate. ${ }^{.4}$ Hence, Madison argued that the legislative, executive, and judiciary departments should be separate and distinct so that no person could " exercise the powers of more than one of them at the same time," $"$ "55 and that in order

v. United States, 272 U.S. 52, 116 (1926) (framers embraced Montesquieu's view that "the maintenance of independence between the legislative, the executive, and the judicial branches was a security for the people").

62 The Federalist No. 47, supra note 45, at 303 (J. Madison).

63 Among the proposals rejected was the establishment of a Council of Revision composed of "the Executive and a convenient number of the National Judiciary," which would have the "authority to examine every act of the National Legislature before it shall operate." See 1 The Records of the Federal Convention 21 (M. Farrand ed. 1911). This proposal to enlist judges into the process of enacting laws was rejected by the Convention in favor of a purely executive veto. Id. at 97-104, 108-10.

Another plan, proposed by Pinckney, called for the President and Congress to have authority "to require the opinions of the supreme Judicial Court upon important questions of law, and upon solemn occasions." Id. at 340-41. The proposal never emerged from the Committee of Detail, to which he submitted it. Another plan, proposed by Morris and supported by Pinckney, called for a Council of State with the Chief Justice as a member and as president of the body in the absence of the President. It provided further that the Chief Justice should "from time to time recommend such alterations of and additions to the laws of the U.S. as may in his opinion be necessary to the due administration of Justice, and such as may promote useful learning and inculcate sound morality throughout the Union." Id. at 324-44. This plan was never voted on by the Convention. The Committee of Detail approved the council, but rejected the last provision. Id. at 364 .

st See W. GwYN, supra note 46, at 104. But see Slonim, supra note 27, at 408-10; see also Scaduto, 763 F.2d at 1204 (Roney, J., specially concurring) (arguing that the Organized Crime Commission is not an improper merging of the branches of government because "the congressional members of the Commission exercise no powers of Congress, and the judicial members no powers of the judiciary, in service on the Commission. Simply put: the judges do not wear their robes in the Commission room.").

One might initially question why the Constitution prohibits senators and representatives from holding other government offices, see U.S. CoNST. art. 1, § 6, cl. 2, but does not impose a similar limitation on judges. The historical background of this provision, however, reveals that it was adopted primarily to prevent the corruption of legislators, who may be tempted to create offices that they would then occupy themselves. See Slonim, supra note 27, at 396-401.

ss The Federalist No. 47, supra note 45, at 312 (J. Madison) (quoting Virginia state 
to maintain the separation of powers the members of each department must be given "the necessary constitutional means and personal motives to resist encroachments of the others." ${ }^{16}$ Thus, in order to maintain the separation of powers, the individuals in each branch must not be the same. Only in this way will they develop the proper loyalties and identification with their own branch to defend themselves against the other branches.

In sum, the separation of powers is based on the notion that in order to protect against the exercise of unchecked power, government must be divided into three independent departments, each with its own allocated functions and personnel. Each branch must be limited to the performance of the governmental function assigned to it, and cannot interfere with the functions of another branch except by means specifically delegated by the Constitution as checks.

\section{B. Separation of Powers Tests}

Given the broad purposes of separation of powers, it should not be surprising that the legal standard for violations of that doctrine has lacked precision. However, the Court's opinions set forth two distinct analytical approaches. Under the first, which might be called the "impairment of function" test, the question is whether the executive's appointment of judges to commissions might impair the function of the judicial branch. If it does, the Constitution forbids it. But even if it does not, judicial service may still be unconstitutional if it fails the "expansion of power" test. This approach asks whether commission service allows judges to perform government functions that lie outside the judicial power. ${ }^{57}$

\footnotetext{
constitution).

se The Federalist No. 51, supra note 45, at 321-22 (J. Madison).

${ }^{87}$ Both Chief Justice Burger and Justice Powell have expressly recognized the existence of these two tests. See INS v. Chadha, 462 U.S. 919, 963 (1983) (Powell, J., concurring) ("Functionally, the doctrine may be violated in two ways. One branch may interfere impermissibly with the other's performance of its constitutionally assigned function. Alternatively, the doctrine may be violated when one branch assumes a function that more properly is entrusted to another.") (citations omitted); Nixon v. Administrator of Gen. Servs., 433 U.S. 425, 514 (1977) (Burger, C.J., dissenting) (arguing that the statute in question violated the separation of powers doctrine because it "exercise[d] a coercive influence by another branch over the Presidency," which is the impairment of function test, and because it was "an attempt by Congress to exercise powers vested exclusively in the President-the power to control files, records, and papers of the office," which is the expansion of power test).
}

As illustrated in Chief Justice Burger's dissent, one branch may take action that both expands its own power and impairs the function of another branch. Interestingly, in the case of judicial service on presidential commissions, it is not the same branch that is expanding 
1. Impairment of Function Test. The general principle that one branch may not act so as to impair the function of another branch has traditionally been the basis of the Supreme Court's separation of powers analysis. ${ }^{58}$ In three recent cases the Court has developed this principle into a test with fairly precise contours.

The current formulation of the impairment of function test originated in United States v. Nixon ("Nixon I"), ${ }^{89}$ which involved a clash between the executive and the judiciary. A court sought to compel disclosure of the tapes belonging to the President, and the President resisted, asserting a claim of executive privilege. ${ }^{60}$ Both sides made arguments sounding in separation of powers-the President argued that disclosure would interfere with the effective operation of the executive branch because confidentiality is essential to his duties, ${ }^{61}$ whereas the government argued that an absolute privilege would compromise the ability of the judicial department "to do justice in criminal prosecutions" and would "plainly conflict with the function of the courts under Article III." "T2 The Court balanced the competing separation of powers claims, ${ }^{63}$ ultimately finding that the judiciary's specific interest in conducting a fair criminal trial outweighed the President's generalized claim of confidentiality. ${ }^{64}$

The Nixon I balancing process was refined in Nixon v. Administrator of General Services ("Nixon II")," where the Court considered Nixon's objections to legislation that required preservation of presidential papers and recordings for government and public use. $^{.8}$ The Court interpreted Nixon $I$ as establishing a two-step separation of powers test. The threshold question is whether action by one branch has the potential to "prevent[] the [affected branch]

its power and impairing another branch. While the executive branch is impairing the function of the judicial branch, the judicial branch is expanding its power.

ss See, e.g., United States v. Klein, 80 U.S. (13 Wall.) 128, 146.48 (1871); Myers v. United States, 272 U.S. 52, 122 (1926); O'Donoghue v. United States, 289 U.S. 516, 530-31 (1933).

B9 418 U.S. 683 (1974).

${ }^{\circ 0}$ Id. at 686 .

1 Id. at 705-76.

(2) Id. at 707.

${ }^{63}$ Id. at 711-12 ("we must weigh the importance of the general privilege of confidentiality of Presidential communications in performance of the President's responsibilities against the inroads of such a privilege on the fair administration of criminal justice") (footnote omitted).

id. at 713 .

os 433 U.S. 425 (1977).

co Id. at 429. The legislation at issue was the Presidential Recordings and Material Preservation Act, 44 U.S.C. $\$ 2111$ (Supp. 1985). 
from accomplishing its constitutionally assigned functions." ${ }^{87}$ If so, a further inquiry is required as to "whether that impact is justified by an overriding need to promote objectives within the constitutional authority" of the branch that is acting. ${ }^{68}$

The Court found that the statute passed the first part of the test, since "nothing contained in the Act renders it unduly disruptive of the Executive Branch and, therefore, unconstitutional on its face." $6 \theta$ The statute did not impair the functioning of the executive branch because the executive branch retained "full control" of the presidential papers. ${ }^{70}$ Accordingly, the Court did not have to decide whether the alleged interference was justified.

The impairment of function test was most recently applied in Nixon v. Fitzgerald ("Nixon III"), ${ }^{71}$ where the Court considered whether a President is entitled to absolute immunity from damages based on his official acts. ${ }^{72}$ The Court found that judicial action allowing a suit for damages constituted potential intrusion into the executive sphere because the threat of civil liability could unduly influence the President's actions. ${ }^{73}$ Accordingly, the Nixon cases required that before a court may exercise jurisdiction over the President it "must balance the constitutional weight of the interest to be served against the dangers of intrusion on the authority and functions of the Executive Branch." tion-the resolution of a private suit for damages-was not needed to serve the broad public interest, the court could not exercise jurisdiction. ${ }^{75}$

Together the three Nixon cases show that the doctrine of separation of powers is violated when one branch's action holds the potential to disrupt the constitutionally assigned function of another branch. Where such potential is present, the action can only be justified by an overriding need that such action be taken.

2. Expansion of Power Test. The Supreme Court has also indicated that the doctrine of separation of powers may be violated merely by one branch expanding its power, even where such expansion does not impair another branch's function. The force with

\footnotetext{
B7 433 U.S. at 443.

Bs Id.

69 Id. at 445.

70 Id. at 444.

757 U.S. 731 (1982).

${ }^{72} \mathrm{Id}$. at 741.

${ }^{73}$ Id. at 749-50.

74 Id. at 754 .

${ }^{28}$ Id.
} 
which this standard applies depends in part on how clear it is that the branch's action falls outside its constitutionally granted powers. Given the overlap between executive and legislative authority, expansive actions by those branches are tested somewhat leniently. ${ }^{76}$ But since the judicial function is defined narrowly and precisely in article III, the Court has strictly limited enlargement of the judiciary's powers. ${ }^{77}$

The expansion of power test was first applied to the judiciary in Hayburn's Case, ${ }^{78}$ where an act of Congress that authorized the judiciary to settle pension claims was held unconstitutional on the ground that it assigned nonjudicial duties to courts. ${ }^{79}$ The judges of the Circuit Court for the District of New York, including Chief Justice Jay and Justice Cushing, wrote:

That by the constitution of the United States, the government thereof is divided into three distinct and independent branches, and that it is the duty of each to abstain from, and to oppose, encroachments on either. That neither the legislative nor the executive branches, can constitutionally assign to the judicial any duties, but such as are properly judicial, and to be performed in a judicial manner. ${ }^{80}$

${ }^{76}$ As Justice Jackson said: "there is a zone of twilight in which [the President] and Congress may have concurrent authority, or in which its distribution is uncertain . . . In this area, any actual test of power is likely to depend on the imperatives of events and contemporary imponderables rather than on abstract theories of law." Youngstown Sheet \& Tube Co. v. Sawyer, 343 U.S. 579, 637 (1952) (Jackson, J., concurring) (footnote omitted). This view is predominant today.

Nevertheless, where executive or congressional action obviously exceeds enumerated powers, the Court will strike it down. Indeed, the Court so held in Youngstown, since it found that the President's seizure of steel mills amounted to "lawmaking," and thus fell outside the powers given by article II. Id. at 587-88. Similarly, the Court held the GrammRudman-Hollings Act unconstitutional because it resulted in "congressional usurpation of Executive Branch functions." Bowsher v. Synar, 106 S. Ct. 3181, 3189 (1986). Under the Act, the Comptroller General, who is controlled by Congress, performed executive functions. According to the Court, this situation violated the principle of separation of powers because in effect it reserved for Congress control of the execution of the laws. Id. at 3192. Other cases have also found violations of the expansion of power test. See, e.g., INS v. Chadha, 462 U.S. 919, 951 (1983); Buckley v. Valeo, 424 U.S. 1, 132 (1976); Reid v. Covert, 354 U.S. 1, 4041 (1957); Kilbourn v. Thompson, 103 U.S. 168, 182 (1880) (Congress may not exercise judicial power by punishing citizens for contempt of its authority); Ex parte Milligan, 71 U.S. (4 Wall.) 2, 21 (1866).

77 See, e.g., United States v. Ferreira, 54 U.S. (13 How.) 40, 52 (1851); Hayburn's Case, 2 U.S. (2 Dall.) 408, 412 (1792); Hobson v. Hansen, 265 F. Supp. 902, 913 \& n.14 (D.D.C. 1967).

78 2 U.S. (2 Dall.) 408 (1792).

"Id. at 412 .

so Id. at 409 n.(a). This statement shows that the concern with the judiciary exercising nonjudicial government functions is based on the notion that the separation of powers 
The same principle-that judges should not perform nonjudicial government functions-motivates the rule against rendering advisory opinions. An advisory opinion offers the judge's views on an issue outside the sphere of an actual case or controversy, and thus outside the range of judicial action authorized by article III. On this principle, the Supreme Court first refused to issue an advisory opinion when asked to advise President Washington in 1793 on several matters of foreign policy. ${ }^{81}$ The Court solidified the rule in Muskrat $v$. United States. ${ }^{82}$

These cases make it clear that judges may not involve themselves in government activities besides the adjudication of cases and controversies. Of course, this does not mean that judges cannot do anything that is not judicial; for example, they can write and deliver lectures. They simply may not perform any function officially connected to the government that is not properly within the judicial sphere.

would be violated if judges exercised executive or legislative powers. The expansion of power test is generally stated as a prohibition against judges exercising nonjudicial government functions, however, because it is easier to determine that a government function is nonjudicial than to state with certainty that the function is executive or legislative. Because any nonjudicial government function is likely to involve some executive or legislative aspects, judges should not exercise such functions even when it cannot be definitely stated that the functions are either executive or legislative.

Another case applying the expansion of power test is Keller v. Potomac Elec. Power Co., 261 U.S. 428 (1923), where the Court held unconstitutional a provision of a congressional act empowering the Supreme Court to hear appeals of decisions concerning the valuations, rates, and regulations of the District of Columbia's Public Utility Commission. Id. at 436-38. Because the appeal would have required the Supreme Court to exercise legislative or administrative power, as opposed to judicial power, it violated the separation of powers. Id. at 441. The Court stated that the principle recognized in Muskrat is that the governmental function of judges is limited to deciding "cases or controversies in such form that the judicial power is capable of acting on them and does not extend to an issue of constitutional law framed by Congress for the purpose of invoking the advice of this Court without real parties or a real case, or to administrative or legislative issues or controversies." Id. at 444; see also Gordon v. United States, 117 U.S. 697 (1864) (reported in Appendix) (Congress may not confer on Court of Claims or Supreme Court jurisdiction to decide cases whose judgments would not be paid until an appropriation is approved by Congress).

${ }^{81}$ See Letter from Thomas Jefferson to the Justices (July 18, 1793), reprinted in P. Bator, P. Mrshkin, D. Shapiro \& H. Wechsler, The Federal Courts and the Federal System 64 (2d ed. 1973). For helpful discussions of this event see Currie, The Constitution in the Supreme Court: 1789-1801, 48 U. CrI. L. Rev. 819, 828-31 (1981); Wheeler, supra note 27 , at 144-55.

${ }_{82} 219$ U.S. 346, 362 (1911). This has been the rule in federal courts ever since. See Currie, supra note 81, at 829 \& nn.68-69; Frankfurter, A Note on Advisory Opinions, 37 HaRv. L. REv. 1002 (1924). Among the cases holding that federal courts are prohibited from rendering advisory opinions are Princeton Univ. v. Schmid, 455 U.S. 100, 102 (1982), Buckley v. Valeo 424 U.S. 1, 11 (1976), and Aetna Life Ins. Co. v. Hayworth, 300 U.S. 227, 240-41 (1937). 
The Court's development of the expansion of power test also reveals two subsidiary points. First, the test logically prohibits the assumption of power by judges acting in their individual capacities as well as in their official capacities. As noted, the separation of powers was meant to ensure that different people would staff the three branches in order to protect against the concentration of power in the same hands. This danger is present whether a judge performs a nonjudicial government duty as an individual or as a court. $^{83}$

Second, the judiciary may not expand its power even if the expansion is approved by the other branches. Although another branch's consent may be helpful when the lines of authority between branches are unclear, ${ }^{84}$ it is irrelevant when a branch performs a function that is clearly outside its domain. Because the judiciary's domain is so well defined, the Supreme Court has disapproved even congressionally authorized expansions of judicial power. $^{85}$ This prohibition is critical to preventing unchecked power: collusion between the branches may be even more dangerous to the separation of powers than brazen appropriation.

os Some have argued that United States v. Ferreira, 54 U.S. (13 How.) 40 (1852), stands for the proposition that judges as individuals, as opposed to courts, may exercise nonjudicial governmental functions. See Slonim, supra note 27, at 406-10; see also Scarfo, 783 F.2d at 375 " Ferreira stands for the proposition that Congress may impose some extrajudicial duties on Article III judges individually-duties that under the separation of powers doctrine may not be imposed on the courts qua courts").

In Ferreira, Congress had passed a statute providing for the settlement of certain outstanding claims by Spanish citizens arising out of the conflict over Florida. Under the statute, the claims were first to be examined by the federal judge for the Northern District of Florida and then reviewed by the Secretary of the Treasury. The question before the Supreme Court was whether an appeal lay from the decision of the District Judge to the Supreme Court. 54 U.S. at 45-46. The Court ruled that an appeal did not lie because "[t]he decision is not the judgment of a court of justice [but instead] is the award of a commissioner." Id. at 47. Ferreira should not, however, be construed as an obstacle to finding that the separation of powers bars judges as individuals from performing nonjudicial government functions, because that question was not before the Court. The Court merely held that the decision could not be appealed because it was not the judgment of a court.

* Consider, for example, Justice Jackson's concurrence in Youngstown Sheet \& Tube Co. v. Sawyer, 343 U.S. 579,635 (1952), where he stated that, in determining whether a particular power can be exercised by the President, a factor weighing heavily in the President's favor is whether Congress has authorized presidential action. But see Nixon v. Administrator of Gen. Servs., 433 U.S. 425, $511-12$ n.6 (1977) (Burger, C.J., dissenting) (noting that the Court held in Buckley $v$. Valeo that "Congress could not constitutionally exercise the President's appointing powers, even though . . . the President had . . . 'approved' the statute [authorizing Congress to exercise the powers] when he signed the bill into law").

ss See supra notes 78-80 and accompanying text. 


\section{Application of the Separation of Powers Tests}

Judicial service on presidential commissions can be constitutional only if it does not impair the judiciary's function or expand the judicial power. Yet neither of these tests provides a bright-line rule. Instead, each depends on the nature of the particular action being challenged. Because presidential commissions vary substantially in power, purpose, and subject-matter, it would be simplistic to generalize about the constitutionality of judicial service on those commissions. Nevertheless, one can construct a framework of analysis that measures the constitutional concerns raised by judicial service on various types of commissions. ${ }^{86}$

The starting point under either test is to define the judicial function; only then is it possible to see if it has been impaired or enlarged. The Supreme Court has characterized the judicial function as "the duty of interpreting and applying [laws] in cases properly brought before the courts," actual controversies arising between adverse litigants, duly instituted in courts of proper jurisdiction." ${ }^{88}$ Hence, the judicial function has two distinct elements: consideration of what the law means and application of the law to cases and controversies.

These elements of the judicial function serve to guide judicial conduct. "Consideration" of laws involves not only interpreting the relevant constitutional, statutory, and common law, but a review of the conduct of the other two branches to determine whether legislation and its execution are consistent with the Constitution. ${ }^{89}$ "Application" of the results of this consideration involves "pronoun[cing] a judgment and carry[ing] it into effect." and controversies" element, on the other hand, serves more clearly to limit the judicial function, by allowing courts to consider only

${ }^{88}$ This comment is concerned solely with whether the membership of judges on presidential commissions is constitutional and not with the constitutionality of the product of the commissions, such as recommended laws or agency action, nor with the constitutionality of actions taken by the commission itself, such as the issuance of subpoenas. The commission's actions may be valid despite the fact that the commission's membership is unconstitutional. See, e.g., Buckley v. Valeo, 424 U.S. 1, 142 (1976) (holding past administrative actions and determinations of the Federal Election Commission valid even though the Commission's membership was unconstitutional).

87 Massachusetts v. Mellon, 262 U.S. 447, 488 (1923).

ss Muskrat v. United States, 219 U.S. 346, 361 (1911).

se See Marbury v. Madison, 5 U.S. (1 Cranch) 137, 178 (1803) (role of the judicial branch in measuring the actions of the executive and legislative branches against the Constitution constitutes "the very essence of judicial duty").

${ }^{30}$ Muskrat v. United States, 219 U.S. 346, 356 (1911) (quoting SAmuel Mrller, Mrler ON THE Constitution 314). 
actual claims between "adverse parties" that are brought before the court in "regular proceedings" established for the protection of rights or the prevention of harm.91

\section{A. Impairment of Function Test}

Under the impairment of function test, the President's appointment of a federal judge to a presidential commission violates the doctrine of separation of powers if it holds the potential for impairing the proper functioning of the judicial branch and the President has no overriding interest in the appointment. ${ }^{22}$ The judicial function to consider and apply laws to cases and controversies could be impaired by judicial service on presidential commissions, which could threaten the impartiality or independence of judges or reduce public confidence in the judiciary. These possibilities for impairment, and the extent to which they threaten the judicial function, are considered in turn.

1. Impartiality. Judicial service on presidential commissions may threaten judicial impartiality because it could bias a judge in favor of viewpoints that he or his colleagues promoted as members of a commission. ${ }^{93}$ This concern is particularly grave since imparti-

91 Id. at 356-57 (quoting In re Pacific Ry. Comm'n, 32 F. 241, 255 (1887)). The case and controversy requirement is grounded in article III, section 2 of the Constitution.

${ }^{22}$ The impairment of function test was applied by both the Eleventh and Third Circuits in determining whether judicial service on the organized crime commission violates the separation of powers, although two variations are of note. First, the Third Circuit applied a stricter version of the impairment of function test than that which was set forth in the Nixon cases by requiring a "substantial" rather than "potential" interference. See Scarfo, $783 \mathrm{~F} .2 \mathrm{~d}$ at 379 . Second, a concurrence in the Eleventh Circuit maintained that the impairment of function test was inappropriate to apply to judicial service on presidential commissions. According to Judge Roney, the Nixon cases "involved the issue of whether the exercise of judicial power encroached on the separate power of the executive" and the organized crime commission did not involve the judges exercising judicial power. Scaduto, 763 F.2d at 1204 (Roney, J., concurring). But this analysis overlooks the fact that the question is whether the executive is impairing the judicial branch's function by appointing judges to commissions.

9s See Note, supra note 27, at 594 ("Justices who have advised the President . . . on a 'correct' course of action will find it difficult to strike down the action they recommended as illegal or unconstitutional if the action is challenged in Court.").

Interestingly, although the Eleventh Circuit in Scaduto was rightly concerned that the presence of the two judges on the Organized Crime Commission might impair the impartiality of the judicial branch, its analysis of this impartiality concern was wrong in at least one respect. The court feared that judges on the commission might become biased against organized crime in general as a result of their increased knowledge of this area. $763 \mathrm{~F} .2 \mathrm{~d}$ at 1196-97. But there is nothing wrong with judges gaining knowledge about a certain area; rather, the impartiality concern centers on the possibility that the judges may become biased in favor of particular government action recommended by a commission on which they or other federal judges have served. 
ality constitutes the essence of the judicial function. In order to consider and apply laws accurately, judges must decide cases based only on the record before them; no preconceptions may govern their decisions. ${ }^{94}$

The extent to which a judge may be biased turns on the characteristics of the presidential commission being considered-the powers the commission possesses, the purpose of the commission, and possibly the subject matter of the commission. Judicial service on commissions with law enforcement powers carries a greater threat to impartiality because it will involve judges in activities that are subject to judicial review..$^{95}$ When the commission's use of these powers is challenged legally, judges may be influenced by the fact that one of their colleagues is a member of the commission: it is as if a federal judge has already ruled on the case. And when a commission has used law enforcement powers, the consequences of possible bias will be more serious, for the use of subpoenas and contempt citations implicates the kind of individual interests that the Supreme Court found to be critical to the judicial function in Nixon $I^{.8}$

Similarly, the threat to impartiality also arises with a commission that is enactment intensive. The product of an enactment-intensive commission-by definition-is more likely to be translated into legislative, administrative, or executive action. A judge's part

94 Lord Coke's maxim, "No man ought to be a judge in his own case," Dr. Bonham's Case, 8 Co. Rep. 107, 118, 77 Eng. Rep. 638, 652 (C.P. 1610), is a fundamental principle in Anglo-American law, and a component of due process. See In re Murchison, 349 U.S. 133, 136 (1955); accord Gibson v. Berryhill, 411 U.S. 564, 577 (1973).

Indeed, the founders explicitly rejected a proposal to include judges in the legislative process primarily because they feared judges might prejudge issues that would come before them later. See 1 The Records of the Federal Convention OR 1787, supra note 53, at 21, 97-99. Samuel King, for example, stated that "the Judges ought to be able to expound the law as it should come before them, free from the bias of having participated in its formation." Id. at 98. Caleb Strong objected that the judges "in exercising the function of expositors might be influenced by the part they had taken, in framing the laws." 2 id. at 75. Nathan Ghorum remarked that the judges "ought to carry into the exposition of the laws no prepossessions with regard to them." Id. at 79.

Similar fears motivate the rule against advisory opinions. See Hayburn's Case, 2 U.S. (1 Dall.) 408, 414 n.(a) (1792); see also Calhoun v. United States, 384 F.2d 180, 185 (5th Cir. 1967); United States v. Gilboy, 162 F. Supp. 384, 397 (M.D. Pa. 1958).

${ }^{93}$ In addition to the exercise of law enforcement powers, other actions by presidential commissions may be challenged in court. See, e.g., Playboy Enters. v. Meese, No. 86-1346 (D.D.C. July 3, 1986) (granting a preliminary injunction prohibiting the Attorney General's Commission on Pornography from publishing the names of pornography distributors in its final report and requiring the Commission to withdraw a letter that had threatened such publication).

${ }^{98}$ See supra notes 59-64 and accompanying text. 
in the formation of that action may influence how other judges consider and apply such enactments. By recommending a law, a judge puts his stamp of approval on it and in effect renders an opinion that it is constitutional or legal. The Warren Commission, for example, recommended that it be made a federal crime to assassinate the President. ${ }^{27}$ If this recommendation had been subsequently enacted, and this legislation came before before a court, Chief Justice Warren's prior recommendation could have influenced its consideration. ${ }^{88}$ Policy-intensive commissions, on the other hand, will rarely see their product-general recommendations of policy-translated directly into discrete government actions.

These impartiality concerns would not disappear even if judges who had served on commissions are disqualified from hearing related cases. ${ }^{92}$ It may be impossible to recuse a judge from every case in which he will apply or interpret legislation he recommended or rejected as a member of a commission. Disqualification also does nothing to alleviate the effect of a judge's service on the impartiality of other judges. ${ }^{100}$ Given the President's interest in

97 See Report of the Warren Commission on the Assassination of President KenNEDY 431-32 (N.Y. Times ed. 1964). Similarly, the Organized Crime Commission made recommendations such as the implementation of drug testing for employees, see N.Y. Times, Mar. 6, 1986, $\S 1$, at 1, col. 1, and the placing of union activities under court supervision, see id. Mar. 7, 1986, \& 1, at 1, col. 2.

-8 See Forkosch, Presidential Murder-The Constitutionality of a Statute Making It a Federal Crime, 19 Sw. L.J. 229, 230 (1965).

" A judge who has an interest in one of several specified personal connections with a case must disqualify himself, see 28 U.S.C. $\$ 455$ (1982), and if a litigant feels that a judge would have a personal bias or prejudice, he may have the judge disqualified by filing a "sufficient affidavit." 28 U.S.C. \$ 144 (1982).

${ }^{100}$ Moreover, disqualifying judges who served on commissions recommending a signifcant number of important laws may impair the judiciary by requiring judges to refrain from hearing a considerable number of cases that may come before them. Presumably, disqualifcation would be required both when the constitutionality of the product is challenged and when the product is applied by the courts. Hence, even if the judge could be disqualified from considering the constitutionality of the legislation, it might be extremely burdensome to disqualify him from every case in which he must apply and interpret the legislation. $C f$. Hearings, supra note 3, at 139 (statement of Alexander Bickel) (discussing wide impact of Jackson's service at Nuremberg on his ability to sit on future cases with the Court). But cf. Scaduto, 763 F.2d at 1204 (Roney, J., concurring) ("The well-known fact that judges frequently are disqualified from handling certain cases and that the judicial branch suffers no power diminution therefrom simply supports a decision that the disqualifying action of an individual judge in an executive position does not create a separation of powers problem. ... The structure of the judicial branch particularly, with its easy cross-assignability of judges of equal power undergirds the notion that the loss of one or two judges on particular cases does not infringe the constitutionally-required duty of the judiciary.").

The time spent on Commission work itself may also impair the judiciary by taking judges away from their judicial work. Justice Jackson's service at Nuremberg, for example, 
staffing commissions with highly respected and influential judges, disqualification seems a particularly weak safeguard. The judges who are most likely to be appointed are those who are most likely to bias other judges, although the effect may be too subtle to warrant disqualification.

Finally, the threat to impartiality also may depend on the subject-matter of the commission. Commissions that consider certain subjects carry less of a threat to impartiality, since it is less likely that courts will be forced to consider the products of such commissions. In particular, if a commission serves to recommend rules concerning judicial practice and procedure, other judges will be less likely to defer to those recommendations; judges themselves are constitutionally empowered to promulgate such rules, and most judges view themselves as having considerable expertise and knowledge about them.

2. Independence. Judicial service on presidential commissions may endanger the independence of the judiciary by subjecting judges to the control and influence of the executive branch. Judicial independence is an aspect of impartiality; it ensures that decisions are made solely on the merits of each case. But when the source of bias is the influence of other branches, the stakes rise considerably. Since it is the judicial function to test the legality of actions taken by the other branches, ${ }^{101}$ this kind of bias not only skews the results in particular cases, it undermines the very legitimacy of the government's actions. ${ }^{102}$

Judicial service on presidential commissions could easily im-

took him away from his judicial duties for a full 17 months, during which time many cases had to be postponed or were deadlocked. See E. GeRHarT, supra note 6, at 257 .

${ }^{201}$ See supra note 89 and accompanying text; see also Kaufman, The Essence of Judicial Independence, 80 CoLUM. L. REv. 671, 700 (1980) ("Because of the unique position of the federal judiciary as the principal guardian of the rights conferred by the Constitution, encroachments upon its protected sphere must be weighed with acute sensitivity.").

${ }^{102}$ Independence is of particular importance to the judiciary, since it lacks the power of "the sword or the purse." See The FeDERALIST No. 78, supra note 45 , at 465 (A. Hamilton). For discussions of the importance of an independent judiciary to the Framers, see Kaufman, supra note 101 , at 687 . Likewise, the judiciary is constantly under majoritarian pressures. See The Federalist No. 78, supra note 45, at 469 (A. Hamilton); see also United States v. Raddatz, 447 U.S. 667, 704 (1980) (Marshall, J., dissenting) (stressing that judges must remain independent for the protection of minorities).

The Constitution provides some protection by insulating judges from dismissal or salary cuts. U.S. CoNST. art. III, § 1; see United States v. Will, 449 U.S. 200, 217-20 (1980) (discussing tenure and salary clause as an aspect of judicial independence). For discussions of the importance of the tenure and salary provisions for an independent and impartial judiciary, see generally Ervin, supra note 50; THE Federalist Nos. 78 \& 79, supra note 45, at 464-75 (A. Hamilton); Kurland, The Constitution and the Tenure of Federal Judges: Some Notes from History, 36 U. CHI. L. Rev. 665 (1969). 
pair independent performance of the judicial function. Members of commissions work in the direct service of the executive and become involved with the policy objectives and desires of the executive branch. In this situation, a judge may be inclined to decide cases in accordance with the policies of the executive branch. $\mathrm{He}$ may also be more inclined to favor that branch in its disputes with private citizens, as well as in cases involving the constitutionality of the executive's action. For these reasons, he may no longer act as a neutral arbiter.

Moreover, the mere possibility of serving on a presidential commission may cause judicial decisions to be influenced by the executive branch. Judges may view such appointments as plums, and may seek to obtain them by deciding cases in ways that please the executive branch. ${ }^{103}$ Judges who hope to obtain higher judicial positions may also feel that they must serve on commissions, thereby lending their prestige to them, in order to please the executive. $^{104}$ In doing so, judges effectively become appendages of the executive branch, thus impairing the consideration element of the judicial function. ${ }^{105}$

Of course, these possibilities are highly speculative, but their potential consequences are serious and real. It is worth looking more closely, then, at which kinds of commissions threaten the greatest harm to judicial independence. Two characteristics of the commission being considered are most important: the purpose of the commission and its subject-matter.

Judicial independence is in the greatest danger when the purpose of the commission is enactment-intensive or the subject-matter is controversial and likely to be reviewed in the courts. These commissions will often be very important to the President because they tend to receive a great deal of publicity and attention. ${ }^{106}$ The

${ }^{303}$ See supra note 24; see also Hearings, supra note 3, at 290 (statement of Arthur Miller) (pointing out that when a judge is asked to participate on a presidential commission "the temptations no doubt are high. Who wouldn't like to be asked for advice by the single most powerful official in the world?").

${ }^{104}$ Noting that Justice Warren at first rejected the appointment to chair the commission charged with investigating President Kennedy's assassination, but capitulated when personally pressed by President Johnson, one commentator has asked: "To what extent was the President's request a directive or a command?" Forkosch, supra note 98, at 231.

${ }^{10 s}$ See generally Kaufman, supra note 101, at 693 ("a statute that gives the judge, even unintentionally, a personal stake in the controversy before him would not only implicate the personal rights of the disadvantaged party, but would also run afoul of the constitutional command that the ultimate power of decision, the judicial power of the United States, remain in the third branch") (citations omitted).

${ }^{100}$ An example of the differences in publicity received by various commissions is seen by contrasting three commissions. The Organized Crime Commission, a highly enactment- 
President is thus more likely to be involved with these commissions and to assert more control over their outcome. Membership on these commissions may also be seen as more prestigious by judges, who may therefore be increasingly tempted to curry favor with the President to gain positions on these commissions. In contrast, because policy-intensive commissions recommend general policy rather than concrete legal actions, and commissions concerning uncontroversial subjects that are less likely to be reviewed by courts often also tend to receive less publicity, the President may be less concerned with these commissions and assert less guidance over them. Judges who serve on these commissions will thus be subject to less presidential influence and control. In addition, these commissions may be viewed as less prestigious, making judges less interested in appointment to them.

These concerns point in the opposite direction for judicial service on a commission concerned with judicial administration. Because these commissions deal with subjects peculiarly within the knowledge and concern of judges, there is not much chance that the President or other executive officials would interfere with or assert control over them. Also, these commissions are not as important politically for the President; by definition they deal only with procedural rules and thus are not likely to raise controversy if they are reviewed in the courts. ${ }^{10 z}$

3. Public Confidence and Respect. A more farsighted view of the judicial function magnifies the concerns expressed so far. When

intensive commission, received considerable publicity in the media as it held hearings around the country, see, e.g., N.Y. Times, June $23,1985, \S 1$, at 26 , col. 1, made recommendations regarding drug-testing programs for federal employees, see id., Mar. 6, 1986, § 1, at 1 , col. 1, and issued controversial reports on such.subjects as the connection of labor unions to organized crime, see id., Mar. 7, 1986, § 1, at 1, col. 2. In contrast, the President's Task Force on Highway Safety, a policy-intensive commission concerning a less-controversial subject matter, raised little public debate by issuing its report, MoBILITy Wirhout Mayhem (1970). In between these extremes are the Warren Commission, which was policy-intensive but received great publicity because of its subject-matter, see, e.g., N.Y. Times, Nov. 30, $1963, \S 1$, at 1 , col. 4 , and the Challenger Commission, which similarly received tremendous publicity. See, e.g., id., Feb. 16, 1986, § 1, at 1, col. 1; id., Feb. 19, 1986, § 1, at 10, col. 1.

${ }_{102}$ The commission must, of course, actually concern matters of procedural administration. See, for example, Hastings v. Judicial Conference, 770 F.2d 1093 (D.C. Cir. 1985), where Judge Edwards held that the Judicial Councils Reform and Judicial Conduct and Disability Act of 1980, 28 U.S.C. $\S \S 331,332,372$ (c) (1982), which gives power to judicial councils to discipline judges, violates separation of powers doctrine if it "affects in any significant way the quintessentially judicial function of substantive decisionmaking." 770 F.2d at 1108 (Edwards, J., concurring) (emphasis in original). This is often difficult to determine. For example, it is unclear whether the Sentencing Commission recently established by Congress should be characterized as dealing with procedural rather than substantive matters. See infra note 126. 
the importance of public confidence and respect for the judicial branch is considered, judicial service on commissions may impair the judicial function even without actual harm to impartiality or independence. For not only must a judge in fact be independent and impartial in resolving disputes, but the public must also perceive this to be the case. ${ }^{108}$

By considering and applying the law objectively, courts serve as effective resolvers of disputes, ${ }^{109}$ thereby providing a substitute for the private methods of retribution to which disputing parties would turn in the absence of a judicial system. ${ }^{110}$ A court's effectiveness in applying the law to the parties depends on its public image as a fair and neutral arbiter of disputes; the parties must be confident that justice is done on their day in court. Accordingly, any action that reduces public confidence in the judicial branch's ability to apply the laws objectively impairs the judicial function.

The extensive reach of the judicial power makes it even more important today for judges to maintain their air of neutrality and impartiality. The scope and effect of judicial decisionmaking now is wider than ever before; courts now address a potpourri of social, economic, and political problems that in times past were left to the other branches or to society itself. ${ }^{111}$ Since the perception of bias

${ }^{108}$ See H.T. RuBin, supra note 10, at 3 (the purpose of the courts is not only to "do justice," but "to appear to do justice.") (emphasis in original); Hobson v. Hansen, $265 \mathrm{~F}$. Supp. 902, 931 (D.D.C. 1967) (Wright, J., dissenting).

108 See Richard Posner, The Federal Courts: Crisis and Rerorm 7 (1985) ("The Supreme Court deals with some of the most passionate disputes in American society, and part of its function should be to cool these disputes.").

110 Judge Posner has wryly observed that the "archaic, ritualistic, apparently nonutilitarian features of the judicial process-the robe, signifying impersonality; the raised bench, symbolizing authority; the special vocabulary, more distant from ordinary speech than is strictly necessary; the oath; the theatrical format of the Anglo-American trial, with its surprises and confrontations and general adversary zest-all seem related to the function of judicial dispute resolution as a substitute for retribution. This explains the odd fact noted by many judges that a plaintiff who loses his lawsuit may nevertheless feel happier for having sued and lost than if he had not sued at all. He has had his day in court, has probably in the course of the trial scored some points against the defendant and at least has forced the defendant to defend himself, and in turn has been led to diffuse the blame for what he may still believe to have been an outrageous invasion of his interests among the defendant, the lawyers, the judges, and some mysterious external entity called the law."). Id. at 6.

11 The decisions of federal judges today often have far-reaching and controversial political, social, and economic consequences. See, e.g., Miller v. California, 413 U.S. 15 (1973) (obscenity); Roe v. Wade, 410 U.S. 113 (1973) (abortion); Reed v. Reed, 404 U.S. 71 (1971) (women's rights); Swann v. Charlotte-Mecklenberg Bd. of Educ., 402 U.S. 1 (1971) (busing); Reynolds v. Sims, 377 U.S. 533 (1964) (legislative reapportionment); Mapp v. Ohio, 367 U.S. 643 (1961) (rights of criminal defendants); Brown v. Board of Educ., 147 U.S. 483 (1954) (racial discrimination and segregation). Several commentators have written on the new regulatory and quasi-legislative role judges have assumed in modern society. See, e.g., Chayes, 
comes more easily when judges are considering those kinds of issues, the need for impartial appearance is all the more acute.

Judicial service on presidential commissions can easily tarnish the appearance of impartiality. If a judge is viewed as having a personal interest in governmental action that makes prejudgment likely, or as being under the wing of the executive branch, public confidence in the judiciary will diminish. ${ }^{112}$ The extent of this effect varies with the nature of the commission. In large part it will mirror the actual effect on impartiality and independence: the public may fear that judicial service on enactment-intensive commissions with powers of law enforcement will endanger the impartiality of judges, and that service on enactment-intensive commissions dealing with controversial subjects likely to be reviewed in the courts will affect the independence of judges. The degree of harm to public opinion, however, is necessarily a function of public awareness of judicial service. Accordingly, if commissions consider noncontroversial subjects, little danger is likely to arise. Similarly, if the subject-matter of the commission concerns judicial administration, even if the public is aware of such service, it is unlikely to be viewed negatively. Because these commissions address judicial subjects, the public is likely to view them as acting in accordance

The Role of the Judge in Public Law Litigation, 89 Harv. L. Rev. 1281 (1976); Freund, New Vistas in Constitutional Law, 112 U. PA. L. Rev. 631 (1964); Wright, The Role of the Supreme Court in A Democratic Society-Judicial Activism or Restraint?, 54 CoRNell L. Rev. 1 (1968). In addition, public distrust of government generally may have increased, thereby requiring an even greater avoidance of the appearance of partiality. See McKay, supra note 27 , at 9.

112 "[P] ublic confidence in the judiciary is indispensable to the operation of the rule of law; yet this quality is placed in risk whenever judges step outside the courtroom into the vortex of political activity. Judges should be saved 'from the entanglements, at times the partisan suspicions, so often the result of other and conflicting duties.' " Hobsen v. Hansen, 265 F. Supp. 902, 923 (D.D.C. 1967) (Wright, J., dissenting) (quoting In re Richardson, 247 N.Y. 401, 420, 160 N.E. 655, 661 (1928) (Cardozo, C.J.)).

In declining to chair a presidential commission to study rubber production, Chief Justice Stone pointed out that when a judge's "action is judicial he may always rely upon the support of the defined record upon which his action is based and of the opinion in which he and his associates unite as stating the ground of decision. But when he participates in the action of the executive or legislative departments of Government he is without those supports. He exposes himself to attack and indeed invites it, which because of his peculiar situation inevitably impairs his value as a judge and the appropriate influence of his office." Mason, supra note 24, at 203-04 (quoting letter from Harlan F. Stone to G.H. Backus (Sept. 19, 1942)).

For a good discussion of how extra-judicial activity affects the prestige of and respect for the Supreme Court, see Note, supra note 27, at 590, 605; see also S. ExEc. REP. No. 7, 80th Cong., 1st Sess., at 1273-74 (1947) (warning by the Senate Judiciary Committee that the practice of using federal judges for nonjudicial tasks "holds great danger of working a diminution of prestige of the judiciary"). 
with the judicial function.

4. Countervailing Executive Interests. Not all actions that impair the judicial function are unconstitutional. Some potential disruptions may be justified by an overriding need to undertake such action. ${ }^{113}$ Application of the impairment of function test thus concludes with the question: Does the President have an overwhelming interest in appointing federal judges to commissions?

For most commissions, the answer is no. The President has many reasonable alternatives to seeking service by federal judges-many other individuals are amply qualified to serve. When a perspective from the legal profession is desired, lawyers, law professors, and former judges could serve as ably as an active federal judge. ${ }^{114}$ Presidents may find it convenient to appoint sitting judges to their commissions, but, as the Supreme Court has noted, the separation of powers doctrine is concerned with values more important than convenience. ${ }^{115}$

In light of these alternatives, the only truly significant executive interest in appointing judges is the desire to add prestige to presidential commissions. ${ }^{116}$ But in terms of the comparison described in Nixon I, ${ }^{117}$ the President's generalized interest in utilizing federal judges in legal advisory roles does not appear to be of the same magnitude as the judiciary's specific and concrete interest in protecting its function. Nor is it as important as the judiciary's interest in allowing individuals to hold the President liable for civil damages, which in Nixon III was held not to outweigh the potential disruption to the executive branch from permitting such liability. ${ }^{118}$

11 See supra text following note 75 .

134 See Hearings, supra note 3, at 86 (statement of Adrian Fisher) ("Although [Justice Jackson as prosecutor at Nuremburg] did a very good job there, it is pretty hard to say that only a Supreme Court justice could serve, particularly when he was serving as a prosecutor. There is a little inconsistency in a man whose permanent role is as a Supreme Court Justice, serving as a prosecutor.").

${ }^{115}$ See INS v. Chadha, 462 U.S. 919, 959 (1983) ("There is no support in the Constitution or decisions of this Court for the proposition that the cumbersomeness and delays often encountered in complying with explicit constitutional standards may be avoided.").

118 See Hearings, supra note 3, at 327 (statement of Ralph Winter).

11 See supra notes 59-64 and accompanying text.

118 See supra notes 71-75 and accompanying text. A case where the threat to the judicial branch was held to be justified by the benefit to another branch is Duplantier v. United States, 606 F.2d 654 (5th Cir. 1979). The Ethics in Government Act of 1978, 28 U.S.C. $\$ 455$ (1982), which requires federal judges to disclose their personal financial interests, was challenged on the grounds that it affected the functioning of the judiciary by jeopardizing judicial independence. The Fifth Circuit held, however, that the act did not violate separation of powers because "[t]he intrusion upon the constitutionally assigned functions of the judi- 
The President may, however, have a strong interest in appointing judges to serve on commissions concerning judicial procedure and administration. Sitting judges typically have unique expertise and knowledge that may be essential in order to shape effective rules and regulations in these two areas. ${ }^{119}$

In sum, the impairment of function test may be violated when presidential commissions have law enforcement powers, are enactment-intensive, or concern controversial and nonjudicial subjects. Such commissions have the potential to disrupt the judicial function, and are not justified by overwhelming presidential interests. Commissions that focus on judicial administration, however, not only offer less potential for disruption but appear justified by strong presidential interests.

\section{B. Expansion of Power Test}

Even commission service that does not impair the judicial function may threaten the separation of powers by expanding judicial power beyond its constitutionally defined sphere. Regardless of the executive's interest, judges may not perform any government function that is not within the judicial power given in article III. ${ }^{120}$ Applying this test to judicial service on presidential commissions therefore requires two distinct inquiries. One must first ask whether the judge is performing a judicial function. If he is not, the function must be nongovernmental in order to avoid constituting an expansion of the judicial power.

1. Is Commission Service a Judicial Function? As noted, the judicial function is to consider and apply the law to cases and controversies. ${ }^{121}$ Consideration involves interpreting and reviewing actions undertaken by the other two branches, while the case and controversy element requires that this consideration and application be conducted only on actual claims between adverse parties.

Judicial service on most presidential commissions has little to do with these elements of the judicial function. Commissions do not decide cases or controversies, and they never apply or interpret

ciary . . . is justified by the promotion of important [congressional] objectives." 606 F.2d at 668.

118 See Hearings, supra note 3, at 60 (statement of L. Ray Patterson) ("The rulemaking power, the power to make rules of procedure, is a function for which the courts are especially qualified .... [A]ppointment of judges to official positions outside the judiciary ... should be avoided except in matters in which the judicial experience makes the appointment of demanding importance").

${ }^{130}$ See supra notes $76-85$ and accompanying text.

${ }^{121}$ See supra notes 87-91 and accompanying text. 
the law in disputes between litigants.

Nor has the historical practice of judicial service on presidential commissions somehow brought the function of commissions within the sphere of judicial power set forth in article III. ${ }^{122}$ Early judges were willing to engage in extra-judicial government service because of necessities that are no longer present. ${ }^{123}$ Indeed, commission service has always been the subject of criticism; ${ }^{\mathbf{1 2 4}}$ the lack of prior constitutional challenge to such service simply results from the difficulty in showing standing to assert such a challenge. ${ }^{125}$

The only presidential commissions for which judicial service may constitute a judicial function are those concerning judicial administration. ${ }^{128}$ The Supreme Court long ago stated that federal

${ }^{122}$ The Third Circuit made this argument in Scarfo, 783 F.2d at 376-78.

${ }^{123}$ For examples of the extra-judicial activities of the nation's early judges, including brief stints by Chief Justices Jay and Marshall as Secretary of State and Chief Justice Ellsworth's service as Minister to France, see generally Slonim, supra note 27, and Wheeler, supra note 27. In England, the judiciary originally grew out of the executive branch, and judges long performed political and administrative duties, in addition to their judicial tasks. See Schwartz, The Other Things that Courts Do, 28 UCLA L. REv. 438 (1981). Thus, early in America's history, judges were still trying to escape the role of the English judges, who had been expected to serve the executive and legislative branches in a variety of extrajudicial capacities, including the rendering of advisory opinions on request. See Wheeler, supra note 27, at 123-24 ("The Jay Court faced a President and Congress anxious to adopt a basic assumption of the English constitution, the assumption that judges were obligated to serve the nation extrajudicially in various ex officio capacities in which their judicial skills would be of use.").

In the early Republic, the judges were also motivated by a desire to please the other two branches of the newly formed government by serving in extra-judicial capacities. See id. There may also have been a shortage of qualified individuals to serve the government early in the nation's history. Thus, the employment of judges, who were legally trained and deemed to possess wisdom, in extra-judicial service was considered to be of great advantage to the government. Id. at 135-39; see also Hearings, supra note 3, at 162 (statement of Arthur Goldberg).

124 See supra notes 24-27 and accompanying text.

125 To obtain standing, an individual must be able to allege that he was injured in fact and that he is within the zone of interests protected by the law in question. See Association of Data Processing Serv. Orgs., Inc. v. Camp, 397 U.S. 150, 152-53 (1970). The Supreme Court has held that a citizen's generalized interest in seeing that his government functions constitutionally is not sufficient to meet the injury-in-fact test. See Valley Forge Christian College v. Americans United for Separation of Church and State, Inc., 454 U.S. 464, 482-87 (1982). Thus, an individual seeking to challenge judicial service on a presidential commission would have to show some concrete, individualized harm to himself as a result of the service, a difficult task. In Scarfo, the requisite harm was found in the government interference and threat to personal reputation resulting from the Commission's compulsion of the defendant's testimony. 783 F.2d at 373-74.

${ }^{126}$ To date no presidential commissions have been established concerning judicial administration. Congress, however, recently established the Sentencing Commission, whose members, including three federal judges, are to be appointed by the President to formulate guidelines to be followed by judges in setting criminal sentences. 28 U.S.C. $\$ 991-998$ (1982). Unlike commissions that formulate rules of civil procedure and evidence, however, one could 
courts, "like every other public political body," possess "the power necessary and proper to provide for the orderly conduct of [their] own business." 127 Congress has also recognized this necessary aspect of the judicial function, as evidenced by the broad role it has assigned the judiciary in this area-the Supreme Court is empowered by the Rules Enabling Act to promulgate rules of practice and procedure for the entire federal court system ${ }^{128}$ and the Judicial Conference of the United States is empowered to appoint judges to committees to recommend such rules. ${ }^{129}$ Because consideration of these issues falls within the judicial power, judicial service on such commissions works no expansion of the judiciary's authority. ${ }^{130}$

2. Is Commission Service a Governmental Function? Service on presidential commissions constitutes an executive function because it aids the executive branch in the performance of its constitutionally assigned duties. The executive function includes those powers specifically vested in the President by the Constitution, as well as the implied powers that are necessary to carry out those enumerated powers. ${ }^{131}$ But the President can hardly perform the

argue that the Sentencing Commission's charge is to recommend rules of substance, as opposed to judicial procedure. Moreover, the Commission is extremely enactment-intensive, as its recommended guidelines become law automatically if not overruled by Congress within six months. Id. § 994 .

127 Wayman v. Southard, 23 U.S. (10 Wheat) 1, 45 (1825). In order to consider laws effectively, judges may issue warrants and subpoenas, hold ex parte hearings, settle estates, and administer bankruptcies. For a list of the managerial and administrative duties of courts, see generally Schwartz, supra note 123 , at 439 . These activities, however, can all be classified as incidental to and in aid of the primary judicial function of deciding cases and controversies. See Chandler v. Judicial Council, 398 U.S. 74, 85 (1970) (noting that for "a complex judicial system [to] function efficiently," judges are entitled to some degree of "statutory framework and power whereby they might 'put their own house in order." ").

${ }^{128} 18$ U.S.C. $\S \S 3771-3772$ (1982 and Supp. II 1985) and 28 U.S.C. $§ 2072$ (1982).

12828 U.S.C. $\S 331$ (1982).

130 This approach is supported by the Eleventh Circuit's recent decision in In re Certain Complaints under Investigation, 783 F.2d 1488 (11th Cir. 1986), where the court rejected a challenge to the Judicial Conduct and Disability Act of 1980, 28 U.S.C. $\$ \S 332(d)(1), 372(c)(9)(A)(1982)$. The Act assigns to judicial officers the power to investigate fellow judges. According to the court, the act differed from judicial service on the Organized Crime Commission because it did "not ask judges to promote some interest lying outside the immediate concerns of the judicial branch," and was concerned not with recommending enforcement measures but with "matters affecting the management and reputation of the judiciary itself." Id. at 1504. The investigatory powers were therefore "ancillary to the administration of the courts," and the act was held constitutional. Id. at 1505.

131 See, e.g., Myers v. United States, 272 U.S. 52 (1926), where the Court held that the President has the implied power of removing executive officers. The Court explained: "As he is charged specifically to take care that [the laws] be faithfully executed, the reasonable implication, even in the absence of express words, was that as part of his executive power he should select those who were to act for him under his direction in the execution of the laws." Id. at 117. 
executive function himself. $\mathrm{He}$ must enlist the aid of prosecutors, tax collectors, administrators, regulators, cabinet members, and countless others, all of whom exercise executive power and perform executive functions when they administer and enforce the law and aid the President in the performance of his function.

The President also enlists the aid of commissions to help him carry out the executive function. Enactment-intensive commissions help him exercise his explicit constitutional powers to recommend and veto legislation. The President often seeks to enact the recommendations of these commissions. ${ }^{132}$ Similarly, although perhaps less directly, policy-intensive commissions help the President perform his executive function of "tak[ing] care that the laws are faithfully executed."1ss As with the President's personal advisors, policy-intensive commissions play an integral role in formulating the general policies of the executive branch. Hence, both enactment-intensive and policy-intensive commissions fulfill important advisory roles within the executive branch. ${ }^{134}$

A second function performed by some presidential commissions is acquiring information for the executive branch. ${ }^{135}$ Commissions are often imbued with law enforcement powers that will help them obtain information from the public. In exercising such powers by compelling testimony, requiring the production of evidence, and issuing grants of immunity, commission members act as extensions of the executive. ${ }^{136}$

In sum, judicial service on most presidential commissions contravenes the expansion of power test because it constitutes the performance by the judiciary of nonjudicial government functions. ${ }^{137}$

132 The findings of the President's Commission on Law Enforcement and Administration of Justice, for example, influenced substantially the 1968 congressional enactment of the Safe Streets and Crime Control Omnibus Act. See H. RuBIN, supra note 10, at 243.

133 U.S. CONST. art. II, § 3.

134 See Federal Advisory Committees, Thirteenth Annual Report of the PresiDENT, supra note 9 , at 1 .

${ }^{13 s}$ See, e.g., In re Comegna, 602 F. Supp. 515, 516 (S.D.N.Y. 1984) ("The [Organized Crime] Commission's function is to ... obtain information on participants in organized crime networks.").

${ }^{136}$ This prosecutorial role was played by members of the Organized Crime Commission. See Public L. No. 98-368 § 6(b), 98 Stat. 490 (1984) (classifying the Organized Crime Commission's members as "investigative or law enforcement officers" for the purposes of access to records and information).

${ }^{137}$ One might argue that the exercise of legislative and adjudicative powers by executive agencies and the federal courts' power to make federal common law also violate the expansion of power test. But these powers are incident to the functioning of both branches. The judicial branch must to some extent decide common law in order to perform its function of deciding cases and controversies. Similarly, in order to administer and execute the 
The functions are nonjudicial because they are not consistent with the judicial function of considering and applying the law to cases and controversies; they are governmental because they fulfill an important advisory and information-gathering role for the executive. Again, however, the degree to which separation of powers concerns are raised may depend on the nature of the commission being considered: the more enactment-intensive a commission is, and the more law enforcement power it possesses, the greater the expansion of power; conversely, there is little or no expansion of power if the subject-matter of the commission is judicial administration.

Returning to the example of the Organized Crime Commission, the framework for analysis suggested by this comment indicates that judicial participation in its operations raised substantial separation of powers concerns. The Commission was enactmentintensive, it possessed substantial law enforcement powers, and its work concerned a nonjudicial subject of wide public interest that was likely to be reviewed in the courts. Accordingly, both of the separation of powers tests indicate that serious constitutional problems could have been avoided if judges had abstained from serving on it.

\section{CONCLUSION}

The doctrine of separation of powers may seem at times little more than a troublesome thorn in the side of efficient government administration. Yet the primary purpose of the doctrine-the prevention of unchecked power-requires constant protection that will often seem inconvenient. Hence, judicial service on presidential commissions, despite its apparent harmlessness, must be scrutinized to ensure its consistency with the separation of powers doctrine.

This comment has presented a framework for analyzing judicial service on presidential commissions in light of their differentiating characteristics. The degree to which separation of powers

\footnotetext{
laws, executive agencies must exercise some legislative and adjudicative functions. See INS v. Chadha, 462 U.S. 919, 967 n.10 (1983) (Powell, J., concurring) (administrative agencies exercise authority that is "judicial in nature," but this function is "part of the agencies' execution of public law"); Industrial Union Dept., AFL-CIO v. American Petroleum Inst., 448 U.S. 607, 684-85 (1980) (Rehnquist, J., concurring) ("in some cases this Court has abided by a rule of necessity, upholding broad delegations of authority where it would be 'unreasonable and impractical to compel Congress to prescribe detailed rules regarding a particular policy or situation") (quoting American Power \& Light Co. v. SEC, 329 U.S. 470, 496 (1904)).
} 
concerns are raised turns on the nature of the commission. If a commission has substantial law enforcement powers or has an enactment-intensive purpose, it is more likely to violate both the impairment of function test and the expansion of power test. If a commission addresses controversial matters likely to be reviewed in the courts, it is more likely to violate the impairment of function test. Finally, if the commission considers issues of judicial administration, judicial service on the commission raises few concerns under either test.

These considerations should be important not only to courts considering challenges to judicial service on commissions, but also to executives who create presidential commissions and judges asked to serve on them. Indeed, it will be a rare case in which an individual will have standing to challenge a particular commission's membership. The balance of power in the national government and the vitality of the judiciary itself thus depend on judges carefully considering the ramifications of their extra-judicial activities and exercising constant self-restraint.

Wendy E. Ackerman 